Rok XIV (2019) | 2 (28) | s. 107-119

https://doi.org/10.12797/LV.14.2019.28.07

Katarzyna Sicíńska ๑

Uniwersytet Łódzki, Łódź

katarzyna.sicinska@uni.lodz.pl

\title{
FORMUŁA WYRAŻANIA SZACUNKU W STRUKTURZE OSIEMNASTOWIECZNEGO LISTU POLSKIEGO
}

Słowa klucze: formuła wyrażania szacunku, grzeczność językowa, epistolografia, język polski w XVIII w.

Keywords: honorificative formula, linguistic politeness, epistolography, Polish language of the $18^{\text {th }}$ century

Struktura osiemnastowiecznego listu polskiego była stosunkowo mocno sformalizowana, determinowały ją bowiem sztywne reguły gatunkowe, w tym etykietalne. Obszarem ich najsilniejszego oddziaływania była tzw. rama tekstowa, wyznaczająca granice tekstu. Zarówno na początek, jak i na zakończenie listu składały się spetryfikowane, a zarazem pragmatycznie sfunkcjonalizowane formuły ${ }^{1}$. Szczególna ich kumulacja występowała w końcowej części listu, co należy łączyć ze strategiczną rolą zakończenia, w którym dochodzi do wygaszenia kontaktu między nadawcą a odbiorcą. Umieszczane w zakończeniu średniopolskich listów formuły wskazywały na wyczerpanie tematu, manifestowały oddanie się łasce, służyły zaleceniu służb, wyrażały szacunek wobec adresata, zawierały pozdrowienia itd. Zwieńczenie całości i zarazem ostateczne zamknięcie tekstu głównego stanowiła subskrypcja (Cybulski

1 Za Markiem Cybulskim przez pojęcie formuły rozumiem „grupę wyrazów wyrażającą określoną intencję i określone wartości, relatywnie trwałą pod względem formalnym i reprodukowaną w konkretnej, powtarzalnej sytuacji pragmatycznej" (Cybulski 2005: 153). 
2001: 32; Sicińska 2017) $)^{2}$. Repertuar i układ wymienionych formuł bywał w konkretnych realizacjach zmienny, jednak zawsze zakończenie było strukturą rozbudowaną, wieloskładnikową.

W swoim artykule chciałabym się przyjrzeć pewnej niezbadanej, a właściwie nawet niezidentyfikowanej dotąd kategorii formuł finalnych występujących w epistolografii doby średniopolskiej, a mianowicie formule wyrażania szacunku³. Bazę materiałową opracowania stanowią oryginalne rękopiśmienne listy z XVIII w. w liczbie 305, pisane przez kilkudziesięciu autorów pochodzenia szlacheckiego ${ }^{4}$. W prezentowanej analizie pod uwagę brany jest aspekt formalny, semantyczny oraz pragmai socjolingwistyczny opisywanych struktur ${ }^{5}$.

$\mathrm{Na}$ wstępie rozważań należy zauważyć, uprzedzając nieco tok dalszej analizy, że formuła wyrażania szacunku była niemal każdorazowo włączana w strukturę składniową subskrypcji, czyli szeroko rozumianego podpisu nadawcy. Subskrypcja miała postać rozbudowanej frazy typu „Iasnie Oswieconego WXMsci Dobrodzieja Osobliwego Zyczliwie Obligowany y Naiunizenszy Sługa N K Woronicz" WorNK6, 51 (1739) czy też „Iestem Iasnie Oswieconego W Xsiązęcej Mci Dobrodzieia najunizęszym Podnuzkem Michał Swatopełk Xze Czetwertynski” CzetwM2, 5 (1751) (Sicińska 2017: 285). Pojawiające się w obrębie tejże frazy wyrażenie, będące określeniem orzeczenia słowno-imiennego ( $w$ wielu realizacjach zastępowanego konstrukcją imiesłowową), stanowiło właśnie sygnalizowaną formułę wyrażania szacunku ${ }^{6}$, np. „Zostaię $z$ Winnym respektem Waszey Xiązęcey Mosci MWMCiw Pana y Dobrodzieia sczerze Zyczliwym Brate $<\mathrm{m}>$ y Sługą Vnizonym Stef. Humiecki"7 HumS5, 29 (1712), ,zostaiąc $z$ głembokim uszanowaniem JOWXMci Dobrodzieja Zyczliwym

2 Złożoność formuły finalnej, kumulującej w sobie kilka formuł grzecznościowych, jest cechą także późniejszej epistolografii (zob. m.in. Kałkowska 1982: 63; Książek 2008: 92-140).

3 Wprawdzie M. Cybulski i A. Pawłowska odnotowują w swoich opracowaniach analogiczne przykłady, jednak ich nie wydzielają pod względem semantycznym i pragmatycznym spośród wielu innych - zbliżonych formalnie - struktur (zob. Cybulski 2003: 106-107; Pawłowska 2014: 83-84).

4 Listy te były przedmiotem mojego opisu w zakresie reprezentacji regionalnych cech południowokresowych (Sicińska 2013), w tej też publikacji znajduje się ich całościowy wykaz oraz system lokalizatorów źródłowych, przeniesionych do niniejszego artykułu. Wprawdzie piszącymi były osoby wywodzące się wyłącznie z Kresów Południowo-Wschodnich, ale, jak zaznacza M. Cybulski, polska etykieta językowa doby średniopolskiej była zasadniczo jednolita, nie wykazywała istotnych regionalnych osobliwości (Cybulski 2010: 102), w związku z czym analizowany materiał można uznać za reprezentatywny dla całego ówczesnego stanu szlacheckiego, a opisywane fakty językowe za typowy przejaw językowej etykiety epistolarnej XVIII w.

5 Punktem wyjścia jest aspekt formalny. Jak zauważa bowiem M. Cybulski, w badaniach historycznojęzykowych, opartych na źródłach pisanych, bezpieczniejszą procedurą metodologiczną jest przyjęcie pierwszeństwa formy językowej, a nie funkcji (Cybulski 2005: 152).

6 W przytaczanych poniżej cytatach całość formuły wyrażania szacunku zaznaczona jest kursywą.

7 Grafia w cytatach z listów została częściowo zmodernizowana, tzn.: wprowadzono znormalizowane kształty liter, np. $y, s, s z, z$ zamiast $\ddot{y}, \int, \beta, z$ itp., uzupełniono niektóre abrewiacje, np. $J e<\mathrm{g}>0$ zamiast Jeo, wprowadzono współczesną normę w zakresie pisowni łącznej i rozdzielnej, 
y Naynizszym Sługo Szczęsny Czacki” CzacSz4, 9 (1763). Wchodząc w skład większej całości składniowo-semantycznej (najczęściej subskrypcji, choć niekiedy także innego elementu struktury tekstu), formuła wyrażania szacunku tworzyła przy tym wyraźnie odrębną strukturę o właściwej sobie formie, semantyce i funkcji. Jej zależność syntaktyczno-semantyczna powoduje jednak konieczność przytaczania w celach egzemplifikacyjnych szerszych kontekstów, nie zaś samej wyizolowanej formuly.

Podstawowym składnikiem formuły wyrażania szacunku był rzeczownik oznaczający szacunek, cześć. W badanych listach owym jądrem formuły bywają rzeczowniki adoracja, cześć, estyma, estymacja, konsyderacja, poważenie, respekt, szacunek, uszanowanie, weneracja:

- adoracja 'cześć, uwielbienie, zachwyt' (SL, SW, SJPD):

„y w dalszy czas od Woli WKMosci chcę mieć dependentcy[ą] y Zostawac $z$ Winna Adoracya Waszey Krolewskiey MCi MW Milosciwe $<$ g $>0$ Pana y Dobrodzieia Nayzyczliwszym y Nayniszym Sługą Stef Humiecki” HumS6, 68-69 (1723; S. Humiecki, woj. pod., do królewicza - Jakuba Ludwika lub Konstantego Władysława, synów Jana III);

„bendąc $z$ iaką naiwieksza Adoratiq Waszei Xięcei Msci Dobrodzieia Brate $<\mathrm{m}>$ zyczliwy $<\mathrm{m}>$ sługą Vnizony $<\mathrm{m}>$. A Łaszcz" ŁaszAM9 (1719; A.M. Łaszcz Tuczapski, woj. bełski, do nieust. księcia);

„Zostaiąc $z$ naygłębsza adoracya JOWXnzney Mosci WMM Pani Dobrodziki Naynizszy Sługa [M H Czacki]" CzacMH2, 27a (1737; M.H. Czacki, ówczesny8 stol. wołyński, do księżnej K. Radziwiłłowej);

- cześć 'szacunek, poważanie, poszanowanie, uznanie; kult, uwielbienie' (SL, SW, SJPD):

„Oswiadczam mię oraz bydz z nalezytą Czcia y Uszanowaniem WWM Pana Dobrodzieja Sercem Kochaiącym Bratem y naynizszym Sługą I A Woronicz" WorJA6, 32v (1771; J.A. Woronicz, ówczesny miecznik owr., do krewnego, I. Woronicza, stol. i sędziego grodzkiego żyt., starosty ostrzskiego);

- estyma 'poważanie, uszanowanie, cześć, szacunek' (SL, SW rzad., SJPD przest.):

np. z naygłębszą zamiast znaygłębsza, naiwiekszą zamiast nai wiekszą itp. Pozostawiono jednak wszelkie inne osobliwości dawnych zapisów.

8 Osoby będące autorami i adresatami listów sprawowały w życiu publicznym różne, $\mathrm{z}$ biegiem czasu na ogół coraz wyższe, funkcje i urzędy. Z punktu widzenia analizy zachowań grzecznościowych istotna jest funkcja i pozycja społeczna piszącego (i odbiorcy) w trakcie trwania korespondencji.

9 W tekstach powstających w dobie średniopolskiej daje się zaobserwować użycie zaimka osobowego ja (tutaj biernikowe mię) zamiast zaimka zwrotnego się. Taki typ składni wynika prawdopodobnie z oddziaływania wzorców łacińskich, choć niektórzy badacze upatrują w tym zjawisku wpływów języka francuskiego (Brajerski 1961: 127-129; Szczepankowska 1999: 274). 
"Zostaię ze wszelką Exteymą ${ }^{10}$ WWM Pana Zeycliwą siostrą y ochoczą sługą I. Woroniczowa" WorJad4, 82 (1763; J. Woroniczowa, kasztelanowa kijowska, do I. Godlewskiego, miecznika malborskiego);

- estymacja 'estyma, poważanie, uszanowanie, cześć, szacunek' (SL, SW rzad., SJPD daw.): „z Stateczno Pisze się estymacio pisze się WWMc Pana Dobr<odzieja> Zyczliwym Bratem y Sługą nayni[z]szym Lw B. Podhorodenski” PodB2 (1770; L.B. Podhorodeński, kaszt. czernihowski, do I. Woronicza, stol. i sędziego grodzkiego żyt., starosty ostrzskiego);

- konsyderacja 'poważanie wśród ludzi; szacunek, respekt' (SL nie notuje, SW rzad., SJPD przest.):

„Mam honor bydz y wyznawac się $z$ Winna Konsyderacya y uszanowaniem Jasnie Wiel<możnego> WMWM W[m] Pana Dobrodzieja Nayniszszym Sługą K J Lipinski” LipKJ6 (1782; K.J. Lipiński, ówczesny podk. latyczowski, do S. Sadowskiego, łowczego bełskiego, st. ropczyckiego i uszyckiego);

- poważenie 'poważanie' (SL, SW daw., SJPD daw.):

„Zostaie z niestarganym nigdy przywi[ę]zaniem, y nalezytym powazeniem JOWXM[c]i Dobrodzieja serdecznie, y na zawsze Kochai[ą]cym Bratem y naynizszym Sług[ą] Seweryn Rzewuski" RzewSJ1 (1776; S.J. Rzewuski, hetman polny kor., do księcia K.S. Radziwiłła, woj. wileńskiego);

„wyznaiąc Mnie bydz zawsze $z$ Wysokim powazeniem y uwielbieniem. WWM Pana Dobrodzieja Naynizszą Sługą C Woroniczowa" WorC2, 66-66v (1750; C. Woroniczowa, ówczesna miecznikowa owrucka, do brata);

- respekt 'poważanie, szacunek' (SL, SW, SJPD):

„Iestem $z$ powinnym respektem Waszey Xcey MCi Kochaiący Brat y unizony Sługa Jozef Łaszcz" ŁaszJA1, 5-6 (1720; J.A. Łaszcz, późniejszy biskup sufragan chełmski, do nieust. adresata);

„zostaiąc $z$ prawdziwym Respektem. JOWXCey MCi Dobrodzieja Nayniższym Sługą Jgnacy Potocki” PotIg6 (1777; I. Potocki, st. kaniowski, do nieust. księcia);

„iestem $z$ naynizszym Respektem Waszey Xięcey Mc Dobrodzieyki moiey prawdz[i]wym y Vnizonym sługą A Szeptycki” SzepAt4, 15 (1730; A.A. Szeptycki, duchowny greckokatolicki, metropolita kijowski, do nieust. księżnej); „będąc $z$ nalezytym y głębokim respektem. JWWMM Pana Dobrodzieia Zyczliwym nainiższym Sługą M Potocki” PotMB2, 15 (1755; M.B. Potocki, st. kaniowski, do J.K. Branickiego, kaszt. krakowskiego, hetmana wielkiego kor.); „Wyznaie zem iest $z$ Nayobowiązańszym Respektem. WWM Pana Dobrodzieja Naynizszą Sługą C Woroniczowa" WorC1, 64 (1750; C. Woroniczowa, ówczesna miecznikowa owrucka, do brata);

10 Grafia autorki listu jest bardzo rozchwiana, niekiedy wręcz uniemożliwia identyfikację wyrazów. 
„Wraz Z Zoną moią $z$ winnym respektem Sciskamy Nogi WWM Dobrodziejstwu Dziatki Nase do Nog upadają WWM Dobrodziejstwu" ${ }^{11}$ WorPS2, 17 (1739; P.S. Woronicz, ówczesny stol. bracławski, do N.K. Woronicza, ówczesnego chorążego owr.);

- szacunek 'cześć, poważanie, poszanowanie, uznanie' (SL, SW, SJPD):

„Na Kozdym zas Mieyscu z prawdziwym szacunkiem wyznawac się nie przestanę JOWXCej MCi Dobrodzieja Szczerze Życzliwym Bratem y Nayniższym Sługą Jgnacy Potocki” PotIg5, 8 (1775; I. Potocki, były st. kaniowski, marszałek ziem generału ruskiego konfederacji barskiej, do nieust. księcia);

„Z nalezytym oraz nieskonczenie Zostawam Szacunkiem $\mathrm{W}<$ ielmożnego> WMWM Pana Dobrodz<ieja $>$ z Serca kochai[ą]cy y $\mathrm{N}<$ aj $>n<i \dot{z}>$ sz $<$ y $>$ Sługa K J Lipinski” LipKJ2, 169 (1774; K.J. Lipiński, ówczesny podk. latyczowski, do nieust. adresata);

„prosze wierzyc ze $z$ wysokim szacunkiem Iezdem WWMCi Pana Dobrodzieia Naynisza Sługa Jozefa Woroniczowa" WorJóza5, 61v (1785; J. Woroniczowa, kasztelanowa bełska, do nieust. adresata);

- uszanowanie 'poważanie, poszanowanie, szacunek, cześć' (SL, SW, SJPD):

„zostaiąc $z$ głembokim uszanowaniem JOWXMci Dobrodzieja Zyczliwym y Naynizszym Sługo Szczęsny Czacki” CzacSz4, 9 (1763; S. Czacki, podcz. kor., do nieust. księcia);

„Zostaię $z$ przywiązanym uszanowaniem JOWXMci Dobrodzieja Szczerze kochającym Bratem y naynizszym sługo Szczęsny Czacki” CzacSz7, 12 (1767; S. Czacki, podcz. kor., do nieust. księcia);

„zostaię $z$ nalezytym uszanowaniem JOWXMci Szczerze Zyczl<i $>$ wym Bratem y Unizonym Sł[u]go Szcz[ę]sny Czacki" CzacSz9 (1779; S. Czacki, podcz. kor., do A. Ponińskiego);

"pise się z powinnym usanowaniem Iasnie WWMM Pani y Dobrodziki na zawsze scyrze zyczliwy [sic] y najunizensym sługo" WorPS6, 53-53v (1762; P.S. Woronicz, stol. bracławski i żyt., do J. Woroniczowej, kasztelanowej kijowskiej);

- weneracja 'cześć, szacunek, poważanie; okazywanie komu lub czemu czci, poważania; wenerowanie' (SL nie notuje, SW, SJPD przest.): „z głęmbokq weneracia zostai[ę] Jas $<$ nie $>$ Os $<$ wieconego $>$ W. X. MCi Dobrod<zieja $>$ Naynizszym sługą y Exoratorem ${ }^{12}$ Jakob Arcyb $<$ isku $>$ p Lw<ow >ski Orm<iański>” AugJS2 (1756; J.S. Augustynowicz, arcybiskup lw. obrządku ormiańskiego, do nieust. księcia).

11 Jest to rzadki przykład włączenia formuły wyrażania szacunku w inną strukturę niż subskrypcja.

12 Według Sł-p exorator to 'ten, kto o coś prosi, coś wyprasza' (od łac. exorare 'wyprosić, wybłagać, przez prośby coś uzyskać'). 
Niekiedy formuła przybierała charakter tautologiczny, np. „Mam honor bydz y wyznawac się $z$ Winna Konsyderacya y uszanowaniem Jasnie Wiel<możnego> WMWM W[m] Pana Dobrodzieja Nayniszszym Sługą K J Lipinski” LipKJ6 (1782; K.J. Lipiński, ówczesny podk. latyczowski, do S. Sadowskiego, łowczego bełskiego, st. ropczyckiego i uszyckiego); "Oswiadczam mię oraz bydz $z$ nalezyta Czcia y Uszanowaniem WWM Pana Dobrodzieja Sercem Kochaiącym Bratem y naynizszym Sługą I A Woronicz" WorJA6, 32V (1771; J.A. Woronicz, ówczesny miecznik owr., do krewnego, I. Woronicza, stol. i sędziego grodzkiego żyt., starosty ostrzskiego).

W skład formuły wchodziły w takich wypadkach dwa rzeczowniki oznaczające szacunek (jednym z nich było zwykle uszanowanie), które pozostawały względem siebie w stosunku współrzędnym, tworząc konstrukcję szeregową.

Wśród rzeczowników konstytuujących formułę wyrażania szacunku znajdują się rodzime derywaty odczasownikowe: uszanowanie (od uszanować) oraz poważenie (od poważać), dawne zapożyczenie niemieckie szacunek (śrwysniem. schatzunge, schetzunge $)^{13}$, pożyczka francuska estyma (fr. estime) oraz liczna grupa latynizmów: adoracja (łac. adoratio), estymacja (łac. aestimatio), konsyderacja (łac. consideratio), respekt (łac. respectus), weneracja (łac. veneratio) ${ }^{14}$ (SJPD). Największą frekwencją odznaczają się w badanych listach rzeczowniki respekt i uszanowanie. Skład leksykalny formuł dowodzi znacznych wpływów łacińskich na język polskiej etykiety epistolarnej w XVIII w., na co zwrócił już uwagę Marek Cybulski, pisząc, iż w czasach saskich „lubowano się [...] w rozmaitych respektach, obserwancyjach, obligacyjach, weneracyjach, addycyjach, submissyjach itd." (Cybulski 2005: 197-198). Znamienne też, że przejęta z języka francuskiego estyma pojawia się dopiero w listach z końca XVIII w., w tym bowiem czasie łacina zaczęła ustępować rosnącym wpływom francuszczyzny. Współcześnie wymienione rzeczowniki mają przeważnie status archaizmów (estyma, estymacja, konsyderacja, poważenie, weneracja).

Przydawki określające podstawowy dla formuły rzeczownik są dość zróżnicowane znaczeniowo: dystyngwowany ${ }^{15}$ (dystyngwowane uszanowanie), głęboki (głębo-

13 Szacunek pochodzi z śrwysniem. schatzunge, schetzunge 'oszacowanie; odebrane pieniądze jako podatek, wykup, kontrybucja; taksowanie' (niem. Schatzung 'szacowanie, ocena; poważanie'). W języku staropolskim, w XV w., szacunk występował w znaczeniu 'oszacowanie, określenie wartości, ustalenie ceny; wartość ustalona na podstawie oszacowania, wyznaczona cena', od XVI w. jako 'cześć, poważanie, poszanowanie', 'określenie wartości, ocena, wycena' (SEBor: 591; Karszniewicz-Mazur 1988: 104).

14 Wszystkie te zapożyczenia łacińskie poświadczone były już w polszczyźnie XVII w., przy czym w XVII w. do rozpowszechnionych należał tylko respekt, stosunkowo często występowała konsyderacja, pozostałe rzeczowniki były rzadko używane (Rybicka-Nowacka 1973: 17-94).

15 Dystyngwowany 'pochodzący ze znakomitego rodu, stojący wysoko w hierarchii społecznej, mający duże znaczenie; godny, szanowany, wielki, znakomity; wytworny, elegancki’ (SJPD). 
kie uszanowanie, głęboki respekt, głęboka weneracja), jednostajny (jednostajny szacunek), należyty (należyte poważenie, należyty respekt, należyty szacunek, należyte uszanowanie), powinny (powinny respekt, powinne uszanowanie), prawdziwy (prawdziwa estyma, prawdziwy szacunek, prawdziwy respekt), przywiazany (przywiazane uszanowanie), stały (stały szacunek), stateczny (stateczna estymacja), winny (winna adoracja, winna estymacja, winna konsyderacja, winny respekt), wszelki (wszelka estyma), wysoki (wysokie poważenie, wysoki szacunek). Funkcję określeń pełnią również formy superlatywne przymiotników: najgłębszy (najgłębsza adoracja, najgłębszy respekt, najglębsza weneracja), najniższy (najniższy respekt), największy (największa adoracja), najobowiązańszy (najobowiązańszy respekt).

Semantyka przymiotników typu należyty, powinny, winny, najobowiązańszy łączy formułę weneracyjną ${ }^{16} \mathrm{z}$ kategorią powinności, która może się też wyrażać $\mathrm{w}$ osobnej, temu tylko celowi podporządkowanej formule ${ }^{17}$. Z kolei przymiotnik przywiązany dowodzi skorelowania kategorii szacunku z kategorią przychylności, również znajdującą swój wyraz w odrębnej, ale zbliżonej do analizowanej, konstrukcji formulicznej ${ }^{18}$. Określenia jednostajny, stateczny, stały kładą nacisk na stałość uczucia szacunku ze strony nadawcy, natomiast leksem prawdziwy służy wzmocnieniu i uwiarygodnieniu wyznania nadawcy. Przymiotnik wysoki odzwierciedla tzw. aksjologię pionu, to znaczy wpisuje się w przeciwstawienie GÓRA - DÓŁ (WYSO$\mathrm{KO}$ - NISKO), które niesie ze sobą przeciwstawienie wartości (DOBRO - ZŁO) ${ }^{19}$. Aspekt wartościujący - poprzez metaforyczne odniesienie do rozmiaru - ma również przymiotnik największy. Przymiotnik głęboki i jego forma superlatywna najgłębszy oraz forma stopnia najwyższego od przymiotnika niski, czyli najniższy, to kolejne metafory przestrzenne o nacechowaniu wartościującym, przy czym niski i głęboki odwołują się najprawdopodobniej do charakterystyki realnego gestu będącego niegdyś wyrazem szacunku, tj. do pokłonu - niskiego lub głębokiego. Pozostają one zatem w związku ze średniopolskimi formułami gestycznymi typu kłaniam

16 Formułę wyrażania szacunku nazywam również formułą weneracyjną lub rewerencyjną od znanych średniopolszczyźnie rzeczowników weneracja i rewerencja oznaczających 'szacunek i poważanie okazywane komuś'.

17 Formuła wyznania powinności ma strukturę zbliżoną do formuły wyznania szacunku, np. „zostaię $z$ niewzruszona obligacyą WXMci Dobrodz[ieia] unizonym sługą Stefan Potocki” (1713; S. Potocki, referendarz kor., do nieust. księcia).

18 Formuła wyznania przychylności może przybrać następującą postać: „Zostaie $z$ serdecznym y nieskończonym przywięzaniem JOWXMCi serdecznie Kochai[ą]cym Bratem y naynizszym Sług[a] Seweryn Rzewuski” RzewSJ3 (1777; S.J. Rzewuski, hetman polny kor., pisarz polityczny, do woj. wileńskiego, księcia K.S. Radziwiłła). Formułom wyznania powinności, przychylności oraz kilku innym zbliżonym do nich formalnie i znaczeniowo konstrukcjom zostanie poświęcone osobne studium.

19 Schemat poznawczy GÓRA - DÓ£ ze swoim nacechowaniem wartościującym należy do uniwersalnych schematów poznawczych w myśleniu człowieka. O wykorzystaniu metaforycznych określeń niski-wysoki w epistolografii pisał m.in. Tadeusz Budrewicz (2000: 207-208). 
nisko (uniżenie), do nóg upadam, czołem bije (zob. Cybulski 2003: 70-73). O tym, że w komunikacji epistolarnej, będącej formą komunikacji pośredniej, występują różnego typu sformułowania o funkcji ekwiwalentów zachowań pozawerbalnych, świadczy też korespondencja późniejszych okresów (zob. m.in. Olma 2009). Zaimek upowszechniający wszelki przez swoje znaczenie kwantyfikujące również nabiera waloru oceniającego.

Warto zauważyć, że formuła wyrażania szacunku, choć mocno skonwencjonalizowana, realizująca jednakowy schemat syntaktyczny „przyimek $z+$ przymiotnik + rzeczownik", wykazuje jednak znaczną wariantywność pod względem składu leksykalnego. Piszący miał do wyboru zarówno różnorodne synonimy rzeczownika szacunek, jak i wielość określeń tegoż rzeczownika, wnoszących do formuły różne odcienie znaczeniowe oraz wymiar wartościujący.

Oprócz tej spetryfikowanej postaci formuły można zaobserwować w badanych listach nieco odbiegające od niej sposoby wyrażania szacunku:

„Z wyznaniem nayszczerszego przywiązania y Uszanowania pisz[ą]c się WWMCi Pana Dobrodzieja Sercem Kochai[ą]cym Bratem y naynizszym Sługą J A Woronicz" WorJA10, 37v (1772; J.A. Woronicz, ówczesny miecznik owr., do krewnego, I. Woronicza, stol. i sędziego grodzkiego żyt., starosty ostrzskiego);

„Przy naywyszym Uszanowaniu Całym Obowiązana zyciem J W” WorJóza9, $72 \mathrm{~V}$ (1795; J. Woroniczowa, kasztelanowa bełska, do F.K. Branickiego, byłego hetmana wielkiego kor.).

Mniej standardowe warianty formuły weneracyjnej częściej występują w listach pisanych przez kobiety, które, jak wiadomo, miały w owym czasie ograniczony dostęp do edukacji, w związku z czym tworzone przez nie teksty odbiegały od powszechnie realizowanych wzorców.

Formuła wyrażania szacunku mogła mieć też charakter cytatowo użytego wyrażenia łacińskiego, co stanowiło przejaw zaznaczającego się w XVIII w. kryzysu polskości obyczaju epistolarnego (Cybulski 2005: 198):

solito cultu 'z powszechną czcią, z należną czcią': „Zostawam Solito Cultu I.O.W.XMci y Dobrodzieja Sczyrze Zyczliwym y prawdziwym y na[j]niszym Sługo W Boreyko" BorW5, 11 (1737; W. Borejko, podstoli owr., do nieust. księcia);

perenni cultu 'z niezmienną czcią': „Zostaię perenni Cultu. JOWXMci Dobrodzieja Szczerze Zyczliwym Bratem y Naynizszym Sługo Szczęsny Czacki” CzacSzz, 14 (1763; S. Czacki, podcz. kor., do nieust. księcia);

pleno cultu 'z pełną czcią': „starac się będę Jego dobroci zasługowac zostaiąc pleno Cultu WWMWM Pana Serdecznie kochaiącym Bratem y naynizszym Słu- 
go Szczęsny Czacki” CzacSz6, 50v-51 (1764; S. Czacki, podcz. kor., do nieust. miecznika żyt.);

profundo Cultu 'z głęboką czcią’: „zostaię profundo Cultu JOWXMci Dobrodzieja Naynizszym Sługo Szczęsny Czacki” CzasSzz, 6 (1763; S. Czacki, podcz. kor., do nieust. księcia);

cum profundissimo cultu 'z najgłębszą czcią): „Nieustanney zatym oddaie się Łasce y Protekcyi pisząc Cum profundissimo Cultu Iasnie Oswieconego WXcey MCi y Dobrodzieia Szczerze Zyczliwym y Nayniszszym Sługą Potocki” PotJoach1, 3 (1750; J. Potocki, st. lw., generał major wojsk kor., do nieust. księcia);

cum particularissimmo cultu ' $\mathrm{z}$ najszczególniejszą czcią’: „Zostawam na zawsze Cum particularissimmo Cultu. Iasnie Oswieconego WXCey MCi y Dobrodzieia Szczerze Zyczliwym y Nayniszszym Sługą Potocki” PotJoach4, 8 (1753; J. Potocki, st. lw., generał major wojsk kor., do nieust. księcia);

ad aras cum profundissimmo cultu ' $\mathrm{z}$ najgłębszą czcią', np. „zostaiąc ad Aras Cum profundissimmo Cultu Iasnie Oswieconego WXCey MCi y Dobrodzieia Szczerze Zyczliwym y Nayniszszym Sługą Potocki” PotJoach8 (1760; J. Potocki, st. lw., generał major wojsk kor., do nieust. księcia);

in omni cultu et veneratione ' $\mathrm{z}$ pełną czcią i poszanowaniem': „y Iestem in omni cultu et veneratione WXM Dobrodzieia prawdziwym y unizonym Sługą Stefan Potocki” PotStefII6, 29 (1706; S. Potocki, ówczesny krajczy kor., do nieust. księcia);

cum submissio cultu et veneratione ' $z$ pokorną czcią i uszanowaniem': „Zostawam cum Submissio cultu et veneratione WXMCi Dobrod<zieja> prawdziwy y unizony Sługa Stefan Potocki” PotStefII7, 36 (1710; S. Potocki, ówczesny st. czerkaski, krajczy kor., referendarz kor., do nieust. księcia);

submissi veneratione 'z najpokorniejszym uszanowaniem': „zostaię submissi veneratione JO Waszey Xięcey Mci Dobrodzieia prawdziwym y Vnizonym sług[ą] A Szeptycki" SzepAt5 (1740; A.A. Szeptycki, duchowny greckokatolicki, metropolita kijowski, do nieust. księcia).

Ośrodek łacińskich formuł wyrażania szacunku stanowią rzeczowniki cultus 'hołd, cześć, uwielbienie' (Sł-p) oraz veneratio 'uszanowanie, uwielbienie' (ibid.). Prawdopodobnie we wzorcach łacińskich należy szukać źródła polskiego wariantu formuły. Warto też zauważyć, że łacińskojęzyczne wersje występują wyłącznie w listach pisanych przez mężczyzn.

Formuła weneracyjna nie miała w tekście epistolarnym, jak to już zostało zasygnalizowane na początku analizy, samodzielnego, odrębnego statusu, łączyła się bowiem składniowo i semantycznie z subskrypcją (bardzo rzadko $\mathrm{z}$ innym typem formuły). Taka zintegrowana formuła subskrypcyjno-weneracyjna stanowiła ostatni komponent tekstu głównego listu (nie licząc dopisków w postaci postscriptum). Z kolei jej poprzednikami mogły być inne, typowe dla zakończenia listu, formuły 
epistolarne albo akty mowy zwyczajowo sytuowane w tymże zakończeniu. I tak formuła ta mogła występować m.in.:

- po formule zalecenia służb:

„a teraz dalszego dla siebie ząndaiąc chonoru [sic] do słuzenia rozkaz[ąm] W. Xięci MCi Dobrod<zieja $>$, z naygłębsząm weneraciąm zostaię Jasnie Osw<ieconego $>$ W. Xięci MCi Dobrodzieja Naynizszym Sługą y [E]xoratorem Jakob Arcyb<isku>p Lw<ow>ski Orm<iański>” AugJS3, 5 (1757; J.S. Augustynowicz, arcybiskup lw. obrządku ormiańskiego, do nieust. księcia);

- po formule oddania się łasce:

„a teraz mnie Łascę oddawszy $z$ Powinnym Respektem piszę się JOWXCej MCi Dobrodzieja Nayniższym Sługą Jg Potocki” PotIg4, 6 (1770; I. Potocki, st. kaniowski, marszałek ziem generału ruskiego konfederacji barskiej, do nieust. księcia);

- po formule oddania się pamięci, sercu, afektowi, miłości itp.:

"Jego Sercu Braterskiemu oddawszy mnie Zostawam Z Uszanowaniem WWMC Pana Dobrodzieja szczerze Zyczliwym Bratem y naynizszym Sługą J A Woronicz" WorJA5 (1770; J.A. Woronicz, ówczesny miecznik owr., do krewnego, I. Woronicza, stol. i sędziego grodzkiego żyt., starosty ostrzskiego);

- po akcie prośby:

„Wielce o tę łaskę prosze, pisząc się z nalezytym Respektem WWMc pana Dobrodzieja Zyczliwym Bratem y Sługą naynizszym Lw B. Podhorodenskj” PodB5 (1770; L.B. Podhorodeński, kaszt. czernihowski, do I. Woronicza, stol. i sędziego grodzkiego żyt., starosty ostrzskiego);

- po akcie życzeń:

„ktorego [zdrowia - K.S.] zyczoc Całym Sercem y prawdziwym pisze Się z powinnym respektem WWMP Dobro $<$ dzieja $>$ Zyczliwym Bratem y Nayniszym Sługo I K Woronicz" WorJóz4, 54V (1738; J. Woronicz, podcz. owr., do brata, P.S. Woronicza, stol. bracławskiego).

Formuła wyrażania szacunku nie stanowiła obligatoryjnego komponentu ramy finalnej listu. Bywają zakończenia listów pozbawione tego elementu:

„Zaczym Supplikuię respektu Panskiego JOW XMci Dobrodzieia azebys te Donacy[ą] dobrotliwie coram actis authenticis approbowac raczył. w czym ządaiąc łaski Panskiey w dozgonnym usług moich obowiązku byc pragne na zawsze J.O.WXMci Pana y Dobrodzieia Szczerze Zyczliwym y naynisszym sługą Paweł Beyzym” BejzP1, 3 (1761; P. Bejzym, ówczesny regent krzemieniecki, do nieust. księcia).

Po akcie prośby następują formuły oddania się łasce oraz oddania usług, a bezpośrednio po nich już tylko subskrypcja. 


\section{Podsumowanie}

Występująca w epistolografii polskiej XVIII w. formuła wyrażania szacunku miała $\mathrm{z}$ reguły postać niesamodzielnego składniowo wyrażenia o strukturze „przyimek $z$ + przymiotnik + rzeczownik", np. zprawdziwym szacunkiem, z głębokim uszanowaniem. Niekiedy przybierała inną, mniej utrwaloną postać, np. przy najwyższym uszanowaniu. Na ogół formuła weneracyjna stanowiła część subskrypcji, tworząc wraz z nią zespoloną formułę subskrypcyjno-weneracyjną. Rzadko bywała włączana w inne elementy strukturalne typowe dla zakończenia tekstu epistolarnego. Zdarzało się, że formuła szacunku współwystępowała z innymi, bliskimi jej formalnie i znaczeniowo strukturami, np. z formułą wyznania przychylności (obie konstrukcje formuliczne pozostawały wówczas w składniowej zależności od subskrypcji).

Zasadniczą funkcją formuły weneracyjnej była funkcja pragmatyczna, polegająca na podtrzymaniu atmosfery grzeczności i uprzejmości w relacji między nadawcą a odbiorcą. Znamienne, że formuła ta sytuowała nadawcę w pozycji podrzędnej w stosunku do adresata, tzn. nadawca przypisywał sobie w akcie komunikacji językowej pozycję niższą niż adresat. Było to zgodne z modelem szlacheckiej grzeczności, która opierała się m.in. na zasadzie dowartościowywania partnera dialogu i podnoszenia jego rangi ${ }^{20}$. Ze względu na swoje finalne usytuowanie w strukturze listu omówiona formuła należała również do wykładników delimitacji tekstu epistolarnego.

Formuły wyrażania szacunku właściwe były przede wszystkim epistolografii osiemnastowiecznej ${ }^{21}$. Stanowiły one częsty, ale nie obligatoryjny składnik zakończenia listu. Ich użycie uzależnione było od czynników społeczno-sytuacyjnych. Stosowano je mianowicie $\mathrm{w}$ listach do osób zajmujących wyższą pozycję $\mathrm{w}$ hierarchii społecznej lub równych rangą społeczną (do członków rodziny królewskiej lub rodzin książęcych, do wysokich urzędników), a ponadto w sytuacji kontaktu o znacznym stopniu oficjalności. Nie zdarza się natomiast użycie omawianej kategorii formuł w listach do osób stojących niżej w hierarchii społecznej od nadawcy listu (np. w listach bogatej szlachty do zarządców dóbr).

20 Zachowania etykietalne podporządkowane są zawsze określonemu modelowi grzeczności. Na szlachecki model grzeczności składały się zarówno reguły uniwersalne, jak np. życzliwe traktowanie partnera, jak i zasady wyróżniające, jak np. manifestowanie solidarności stanowej, grzecznościowe podnoszenie rangi odbiorcy, okazywanie szczególnego szacunku niektórym odbiorcom, dowartościowywanie wybranych członków społeczności szlacheckiej (Wojtak 1992: 34, 1999: 205).

21 Nie zaobserwowałam ich w listach z XVII w., stanowiących bazę materiałową wspomnianego opracowania poświęconego polszczyźnie południowokresowej (Sicińska 2013). Z kolei w drugiej połowie XVIII w. zaczęła się zmieniać struktura społeczna szlachty polskiej, co pociągnęło za sobą także zmianę modelu grzeczności językowej. Z czasem tradycyjne średniopolskie formuły grzecznościowe wyszły więc z użycia. 


\section{Skróty}

daw. - dawny; fr. - francuski; kaszt. - kasztelan; kor. - koronny; lw. - lwowski; łac. - łaciński; niem. - niemiecki; nieust. - nieustalony; owr. - owrucki; pod. - podolski; podcz. podczaszy; podk. - podkomorzy; przest. - przestarzały; rzad. - rzadkie; st. - starosta; stol. stolnik; śrwysniem. - średnio-wysoko-niemiecki; woj. - wojewoda; żyt. - żytomierski

\section{Stosowane znaki}

[ ] - odczytanie niepewne

$<>-$ uzupełnienie skrótu

\section{Literatura}

Brajerski T., 1961, O języku „Pieśni” Konstancji Benisławskiej, „Rozprawy Wydziału Historyczno-Filologicznego Towarzystwa Naukowego KUL”, 22, Lublin.

Budrewicz T., 2000, Intytulacje i submisje w listach pisanych do Józefa Ignacego Kraszewskiego, [w:] J. Sztachelska, E. Dąbrowicz (red.), Sztuka pisania. O liście polskim w wieku XIX, Białystok, s. 193-209.

Cyвulski M., 2001, Formy nawiązania i zakończenia kontaktu $w$ dawnej polszczyźnie (w XVI-XVIII wieku), [w:] A. Kowalska, O. Wolińska (red.), Studia historycznojęzykowe, „Prace Naukowe Uniwersytetu Śląskiego w Katowicach”, „Prace Językoznawcze”, 26, Katowice, s. 29-36.

Сyвulski M., 2003, Obyczaje językowe dawnych Polaków. Formuly werbalne w dobie średniopolskiej, Łódź.

Cyвulski M., 2005, Obyczaje językowe w dobie średniopolskiej, [w:] S. Borawski (red.), Rozprawy o historii języka polskiego, Zielona Góra, s. 149-211.

Cyвulski M., 2010, Podziały społeczne i terytorialne odzwierciedlone w formułach dawnej etykiety językowej, [w:] M. Kuźmicki, M. Osiewicz (red.), Żywe problemy historii języka, „Prace Komisji Językoznawczej Poznańskiego Towarzystwa Przyjaciół Nauk. Wydział Filologiczno-Filozoficzny”, t. 55, Poznań, s. 99-116.

KaєкоwsKa A., 1982, Struktura składniowa listu, „Prace Instytutu Języka Polskiego”, 47, Wrocław.

KARSZNiewiCZ-Mazur A., 1988, Zapożyczenia leksykalne ze źródła niemieckiego we współczesnej polszczyźnie, „Acta Universitatis Wratislaviensis”, nr 736, „Germanica Wratislaviensia”, 59, Wrocław.

Ksı_̨żEK E., 2008, Tekst epistolarny w świetle etykiety językowej, „Prace Monograficzne Akademii Pedagogicznej im. KEN w Krakowie”, nr 478, Kraków.

Olma M., 2009, Językowe ekwiwalenty gestów w korespondencji małżeńskiej Heleny Pawlikowskiej, „LingVaria” nr 1 (7), s. 193-204.

PawıowskA A., 2014, Formuły werbalne polskiej etykiety językowej od połowy XVIII do lat sześćdziesiątych XIX wieku. Analiza socjolingwistyczna, Łodź.

RYBICKA-NowACKA H., 1973, Rzeczowniki zapożyczone z łaciny w języku polskim XVII wieku (na materiale literatury pamiętnikarskiej), „Prace Językoznawcze PAN”, t. 70, Wrocław. 
SEBor: W. Boryś, Słownik etymologiczny języka polskiego, Kraków 2005.

SicIŃsKa K., 2013, Polszczyzna południowokresowa XVII i XVIII wieku (na podstawie epistolografii), Łódź.

SicińsKa K., 2017, Formuły subskrypcji w korespondencji z terenu Kresów Południowo-Wschodnich (XVII-XVIII wiek). Cz. 1, [w:] P. Borek, M. Olma (red.), Epistolografia w dawnej Rzeczypospolitej, t. VII: Literatura, historia, język, „Biblioteka Tradycji”, Seria Druga, nr 154, Kraków, s. 277-298.

SJPD: W. Doroszewski (red.), Słownik języka polskiego, Warszawa 1958-1969.

SL: S.B. Linde, Słownik języka polskiego, t. I-VI, Warszawa 1807-1814, [on-line:] http://kpbc. umk.pl/dlibra/publication?id $=8173 \&$ from $=\&$ dirids $=1 \&$ tab $=1 \& l p=1 \& Q I=($ dostęp: 14 VII 2019).

SŁ-P: M. Plezia (red.), Słownik łacińsko-polski, Warszawa 1959-1979.

SW: J. Karłowicz, A.A. Kryński, W. Niedźwiedzki (red.), Słownik języka polskiego, Warszawa 1900-1927, [on-line:] http://ebuw.uw.edu.pl/dlibra/publication?id=254 (dostęp: 14 VII 2019).

SzCZEPANKowska I., 1999, Składnia XVIII-wiecznej polszczyzny kresowej wobec wpływów obcych (na materiale korespondencji K.S. Radziwiłła), [w:] B. Nowowiejski (red.), Polszczyzna północno-wschodnia, 2, Białystok, s. 263-277.

Wojtak M., 1992, Wybrane elementy staropolskiej etykiety językowej, [w:] J. Anusiewicz, M. Marcjanik (red.), Polska etykieta językowa, „Język a kultura”, t. 6, Wrocław, s. 33-40.

WoJTAK M., 1999, Staropolska etykieta językowa jako obraz relacji międzyludzkich (wybrane zagadnienia), [w:] A. Pajdzińska, P. Krzyżanowski (red.), Przeszłość w językowym obrazie świata, „Czerwona Seria” Instytutu Filologii Polskiej UMCS, 13, Lublin, s. 205-216.

\section{The Honorificative Formula in $18^{\text {th }} \mathrm{C}$. Polish Letters Summary}

The paper discusses, from the formal, semantic, pragma- and sociolinguistic point of view, the honorificative formula that constituted one of the components of the final part of an epistolary Polish text of the $18^{\text {th }}$ century. Most commonly, it took the shape of a conventionalized phrase which consisted of the preposition $z$ ('with'), an adjective, and a noun; e.g. zprawdziwym szacunkiem 'with true respect'. The formula was syntactically dependent, as it was part of a larger whole - nearly always the subscription, i.e. the broadly understood signature of the author of the letter. The lexical composition of the formula showed considerable diversity. The nouns that constituted it include estymacja 'esteem', poważenie 'reverence', szacunek 'respect', weneracja 'veneration', and others. The attributes that described the main stem of the formula were also characterized by notable semantic diversity. Moreover, the honorificative formula could also appear in the form of a Latin quotation, e.g. profundo cultu. The usage of the formula depended on social and situational factors, namely it was used in letters to people of equal or higher social status (e.g. to members of princely families), as well as in highly official situations. 